\title{
ENGINEERING ETHICS IN ISLAM: AN EVALUATIVE AND COMPARATIVE STUDY BETWEEN CODE OF ETHICS OF INSTITUTION OF ENGINEERS, BANGLADESH (IEB) AND CODE OF PROFESSIONAL CONDUCT OF BOARD OF ENGINEERS MALAYSIA (BEM)
}

\author{
MUHAMMAD AMANULlaH \\ Department of Fiqh and Usul al-Fiqh, \\ Kulliyyah of Islamic Revealed Knowledge and Human Sciences \\ International Islamic University Malaysia, \\ Jalan Gombak, 53100 Kuala Lumpur, Malaysia. \\ amanulllah@iium.edu.my
}

\begin{abstract}
During the past two centuries or so a number of buildings and bridges had been structurally failed and collapsed all over the world. Some of these incidents caused a sizeable number of human casualties. For instance, collapse of Tay Bridge in 1879 killed at least sixty persons. Beside the problems related to their design and construction, probably the failure to follow engineering ethics properly was partially responsible for these incidents. Growing engineering professionalism during the nineteenth century gave rise to the development of a number of famous engineering societies, such as American Institute of Electrical Engineers (AIEE ( (1884), American Institute of Mining Engineers (AIME) (1871), etc. On the other hand, responding to series of significant structural failures mentioned above, some engineering societies developed formal codes of ethics. Following these societies, engineers of Bangladesh (previous East Pakistan) established Institution of Engineers, Bangladesh (IEB). Likewise, Malaysian engineers established Board of Engineers Malaysia (BEM). Both of these societies have their codes of ethics. Islam also has offered a number of ethics to be followed by the engineers. Analyzing the related verses of the Qur'an and ahadith of the Prophet (pbuh), this paper intends to highlight these Islamic ethics and in light of them, tries to evaluate the codes of ethics of these two societies and compare between them. The paper may conclude that although the codes of ethics of IEB and BEM are supported by Islamic ethics they require further modification.
\end{abstract}

ABSTRAK: Sejak lebih kurang dua abad kebelakangan ini, banyak binaan yang gagal dari segi strukturnya dan juga jambatan yang runtuh di merata dunia. Sesetengah tragedi yang berlaku juga mengakibatkan kehilangan nyawa manusia. Contohnya, robohnya Jambatan Tay pada 1879 telah meragut nyawa lebih kurang enam puluh orang. Selain daripada masalah yang berkaitan dengan reka bentuk dan pembinaanya, mungkin juga kegagalan untuk mematuhi etika kejuruteraan merupakan ssebahagian daripada penyebab tragedi-tragedi ini. Pertumbuhan keprofesionalan kejuruteraan dalam kurun kesembilan belas memberikan pertumbuhan pesat terhadap perkembangan beberapa pertubuhan kejuruteraan yang terkenal, seperti Institut Jurutera Elektrikal Amerika (American Institute of Electrical Engineers (AIEE)-1884), Institut Jurutera Perlombongan Amerika (American Institute of Mining Engineers (AIME) -1871) dan sebagainya. Sebaliknya, dalam memberi respons terhadap kegagalan struktur yang signifikan di atas, beberapa persatuan kejuruteraan telah membangunkan beberapa kod etika formal. Berdasarkan kepada pertubuhan-pertubuhan ini, jurutera Bangladesh (yang sebelum ini dikenali sebagai Pakistan Timur) menubuhkan Institut Jurutera Bangladesh 
(Institution of Engineers Bangladesh (IEB)). Jurutera Malaysia pula menubuhkan Lembaga Jurutera Malaysia (Board of Engineers Malaysia (BEM)). Kedua-dua pertubuhan ini mempunyai kod etika masing-masing. Agama Islam juga menyenaraikan beberapa etika yang perlu diikuti. Dengan mendalami ayat-ayat Al-Quran dan hadis Rasullullah yang berkaitan, kertas ini bertujuan menekankan etika-etika Islam dan juga mengkaji kod etika kedua-dua pertubuhan ini dan membuat perbandingan. Kertas ini mungkin merumuskan bahawa walaupun kod etika $I E B$ dan $B E M$ disokong oleh etika Islam, namun beberapa pendekatan harus diubah.

KEYWORDS: engineering ethics; Islamic ethics; IEB; BEM; evaluation

\section{INTRODUCTION}

Different scholars give different definitions of engineering ethics. The researcher does not want to discuss these definitions [1]. Rather, he intends to define it according to Islamic legal system. He maintains that in Islam engineering ethics are a set of rules and principles that an engineer should follow in his professional life [2]. A partial reason of the collapse of a number of buildings and bridges in the past in different parts of the world was probably the failure to follow engineering ethics properly. Being faced by these incidents, a number of engineering societies in the West developed ethics for engineering profession by using their intellectual capabilities without looking into what the divine religions might have to say about them. Although a number of these man-made ethics are in conformity with what Islam or any other divine religion might have regarding them, the intention of these societies was neither to follow any religion nor to take the life hereafter into their consideration. Following these societies, engineers of other countries including Muslim countries also developed their code of ethics regardless of considering whether they are originated from Islam or not. During recent years an attempt has been made to develop Islamic ethics for engineering. One of such attempt is the book written by Abdi Omar Shuriye and Ahmad Faris Ismail [3]. It is a good introductory book. But by and large, this book discusses some Qur'anic values for the study of a number of engineering disciplines, and seldom touches on ethics that should be followed by engineers in their professional life. This research paper intends to deduce professional ethics for engineering from Islamic sources, i.e. the texts of the Qur'an and ahadith of the Prophet (pbuh), so that these ethics would be called Islamic ethics and they would be concerned with the life hereafter besides taking this worldly life into consideration. Following the discussion of these Islamic ethics, the researcher also quotes the codes of ethics of two engineering societies, i.e. Institution of Engineers, Bangladesh (IEB) and Board of Engineers Malaysia (BEM). Finally, he attempts to evaluate these two codes of ethics in light of Islamic ethics of engineering, make a comparison between two of them and strives to propose some suggestions to improve these codes in future.

\section{ISLAMIC ETHICS OF ENGINEERING}

\subsection{Obedience and Compliance}

a. Like any other worker, employee or officer, an engineer should be obedient to his employer and other officers under whom he performs his duty. Allah said: "O you who believe, obey Allah and obey the Messenger and those charged with authority among you"[4] According to this verse, an employer or a head of an office or company is charged with a kind of authority. The one who works under him, whether he is an ordinary worker or an engineer is obliged to obey him. 
b. An engineer should follow the prescribed code of ethics of his own organization in which he is a member. Likewise, he should follow the rules and regulations of the office or company where he is posted. Based on the verse quoted above, following these rules becomes an obligation for an engineer because a part of the obedience to the authority is related to follow the rules adapted by it.

\subsection{Public Interest and Welfare}

a. An engineer should give priority and utmost importance to the public health and safety during doing any work related to his profession. This is because this type of priority is closely related to one of the famous higher objectives of the Shari ah, i.e, protection of life (hifz al-nafs). He must take all different types of precaution before commencing any work so that the public health and safety will be secured and ho harm will be inflicted to them.. Allah said: "If anyone saved a life, it would be as if he saved the life of whole people."[5] The Prophet (pbuh) said: "Harm neither should be inflicted [to any one] nor should be reciprocated."[6]

b. An engineer should not involve himself in any development project that may be beneficial for contemporary generation but it will be harmful for long term or for the future generations.

c. An engineer should not be involved in a project that is harmful for the environment.

d. In order to maintain safety of the public and safety of the workers and employees who work under an engineer for developing a project, he should offer them proper safety guidelines regularly.

e. An established Islamic principle is that if any contradiction occurs between personal/individual interest and public interest, personal interest should be sacrificed for the sake of public interest. An engineer should follow this principle in giving his opinion in favor or against commencement of a new project or in erecting of a new business complex. All these sub-points are supported by the hadith that said that no harm should be inflicted to anyone.

\subsection{Being Trustworthy and Responsible, and Being Free from Cheating}

a. In performing his duty, an engineer should be reliable and trustworthy.

b. He should try to fulfill his duty accurately.

c. He should be careful about his responsibility on his subordinate employees and workers. Allah said: "Surely Allah orders you to fulfill your trustworthiness to the one who deserves it."[7] The prophet said: "The one who does not have trustworthiness does not have perfect faith." [8]

d. An engineer must not cheat his employer, client or any other party. Allah said: "O people fulfill measure (mikyal) and weight (mizan) justly and do not reduce things for people."[9] Although this verse forbids cheating in measuring and weighing, this forbiddance is applicable for any type of cheating including cheating in engineering profession. Cheating also causes one to be out of Muslim community. The Prophet said: "The one who cheats is not one of us." [10]

\subsection{Avoidance of Bribery}

a. In order to receive any project for his company or employer from the government or any other authority or a larger company, an engineer should not offer bribe to any party involved in it.

b. He also should not pay bribe to any party for his own promotion or any other personal benefits. 
c. Likewise, in order to provide any work or any benefit to any party, he himself should not receive bribe from that party.

The prophet (pbuh) said: "Allah curses the one who offers bribe [to others], or receives it [from others]."[11] According to this hadith, since Allah curses people who are involved in giving or taking bribe, all types of bribes including what is practiced by some engineers are forbidden in Islam.

\subsection{Supervision, Checking and Writing Reports}

a. If an engineer is given the responsibility to supervise other engineers or employees or workers, he should do this job by himself accurately without depending on others. Likewise, he should maintain a continuous record of his supervision, so that it will be easier and accurate to keep track of gradual progress of a work.

b. If he is given the charge to investigate a project or some works related to it, he should do it by himself and do not depend on others in doing this task. The Prophet said: "Take account of yourself before you are accounted for."[12] Keeping progress report of a work and doing it personally are considered parts of taking account of oneself, which is applicable for every Muslim including an engineer. The Prophet also said: "Every one of you is considered to be a caretaker, as well as responsible for those who are under his care."[13] The phrase "every one of you" in this hadith is a general expression that addresses all Muslims including an engineer. Therefore, an engineer is considered caretaker and responsible for those employees who work under him. He should guide them properly, check their performance and supervise their daily activities.

c. Likewise, he should not depend on speculation or rumor in doing his investigation. Rather, he should base his opinion on practical findings. Allah said: "O you who believe, avoid much of speculation because some speculation is sin." [14] According to this verse, some speculation that leads to tell a lie is not acceptable. Therefore, speculation should not be the basis for an engineer to do the job of investigation. Allah also said: " $\mathrm{O}$ you who believe, if an impious person brings a message, you should critically examine it."'[15] According to this verse, rumors that come from any quarter should not be believed without examining it. An engineer, therefore, should not depend on rumors without examining them practically.

d. During his supervision and checking, if an engineer finds that an employee has committed a mistake or showed negligence in doing his duty, the supervising engineer should not fire this employee without giving him chance to correct him by showing him his mistake and warning him. Islam encourages forgiving each other unless it is related to the right of an individual.

Allah said: "Hold to forgiveness."[16]

e. If an engineer is given the charge to write a report on a complaint against an employee, office, company, supplier, or contractor, he should be neutral and just in his writing. In order to be just, he should not try to mention only negative or only positive points of the complained party. Rather, he should explain both negative and positive points. Allah said: "Surely Allah orders you to do justice."[17] Writing only negative or only positive points is considered to be injustice and hence it goes against this command of Allah. 
f. If an engineer is requested to write a report, he should not delay to complete this task. Rather, he should maintain the deadline. Likewise, if he receives any complaint, he should respond to it promptly.

g. An engineer should be meticulous in his checking works of others, or in his writing a report, or issuing a certificate of completion of a work. Both $\mathrm{f}$ and $\mathrm{g}$ are supported by a hadith in which the Prophet indicated that Allah loves those who try to perfect their works as much as they can.

\subsection{Truthfulness, Sincerity, Transparency and Upholding Integrity and Dignity}

a. An engineer should be truthful in his public statement about his ability, area of specialization and capacity to do the works. Allah said: "O you who believe, fear Allah and stay with truthful people."[18] According to this verse, Muslims including engineers are not allowed to lie in their public statement. They are also not allowed to claim to know what they do not know. Allah said: "And pursue not that of which you have no knowledge; for every act of hearing, or of seeing, or of (feeling) in the heart will be enquired into (on the Day of Reckoning)."[19] In a hadith the prophet said: "The one who cheats us is not one of us."'[20] In another hadith the prophet said: "A truthful and trustworthy businessman will stay with the prophets, truthful people and martyrs [on the Day of Judgment]."[21] Likewise, telling a lie about own quality and capacity is considered to be a sign of hypocrisy. The Prophet said: "Signs of a hypocrite are three: if he talks, tells a lie; if he promises, he violates; and if he is entrusted, he betrays."[22]

b. According the texts, mentioned above, an engineer should be transparent in dealing with financial aspects of a project.

c. According to the same texts, an engineer should uphold the integrity and dignity of his profession. Telling a lie or giving incorrect information about own capacity or specialization is against this integrity and dignity.

\subsection{Helping the Poor}

a. An engineer should have the intention to help poor people. If a person, because of his poverty, is unable to pay the high fees for a design for his house, the concerned engineer or his employer should receive the reduced charge for it. The Messenger of Allah (pbuh) said: "The one who helps his brother for his need Allah will help him [this helper] for his need...."[23] The Prophet also said: "The one who releases a believer from an anxiety of this world Allah will release him from an anxiety of the Day of Resurrection. And the one who helps a poor by making his life easy Allah will help him by making his life easy in this world and life hereafter...."[24]

\subsection{Avoidance of Building Places for Committing Vices}

a. A Muslim engineer should not participate in building any business complex that is known from the beginning that it will be used for committing vices and obscene deeds which are forbidden in Islam.

b. A Muslim engineer should not make the design for business complexes that are known to be utilized for committing obscene deeds. Allah said: "And He [Allah] forbids obscene deeds." [25] He also said: "Those who love (to see) that obscene deeds are spread among the believers, will have a painful punishment in this life and in the Hereafter." [26] In a third verse, He said: "You should not approach the obscene deeds."[27] Making design of a business complex or building it knowingly that it will be used for vices and obscene activities is considered a type 
of participation in spreading these vices. Therefore, according to these verses, an engineer or any other Muslim should not involve himself in doing so. Likewise, Allah said: "O you who believe, eat from good (lawful) foods that I gave you as sustenance."'[28] The verse indicates that we are not allowed to earn our sustenance from forbidden sources. The Prophet said: "Seeking lawful sustenance is obligatory for every Muslim.”[29] A Muslim engineer, therefore, is not allowed to involve himself in any project that is forbidden in Islam because it will cause his sustenance to be forbidden.

\subsection{Avoidance of Developing Harmful Soft Wires}

a. A Muslim engineer should not develop any soft wires that are harmful for others, such as developing of viruses that can destroy the contents of the computers of other people. This point is supported by a hadith where the Prophet forbade inflicting harms to others.

b. A Muslim engineer is not allowed to develop any soft wire on obscene entertainments. This point is supported by the verses of the Qur'an discussed under b) of sub-section 8 .

\subsection{No Conflict of Interest}

a. If an engineer is an employee under any government office or any company, he should uphold the interest of this office or company. If any conflict of interest occurs, he should not do anything that goes against the interest of this office or company.

b. If he receives any fees for consultancy out of his regular duty to this office or company, he is supposed to let his office know this. Both of these points are related to inflicting harm to the employer or the office or company. According to a hadith of the Prophet, inflicting harm to others is not allowed.

\subsection{Work for Sustainable Development}

Islam encourages development works. An important type of sustainable development is to develop a piece of unowned land by making it suitable to cultivate or dwell on it, or to do business on it. The Prophet said: "Whoever develops a piece of land that does not belong to anyone deserves it most."[30] He also stated: "People are servants of Allah and lands belong to Him. Therefore, whoever develops any piece of wasteland; it belongs to that individual..."[31] An engineer should try his utmost to participate in sustainable development. He should abide himself by Islamic conditions of doing this type of development. An important condition to make a development work as sustainable development is that it should be beneficial for both present and future generations.

\subsection{Avoidance of Unfair Competition}

a. Islam encourages striving for good deeds individually as well as collectively. Allah said: "Then strive together (as a race) towards all that is good...."[32] Islam also encourages mutual collaboration for doing good deeds that include beneficial engineering works and projects. Allah said: "Help each other in righteousness and piety, but do not help each other in sin and rancor."[33] Thus it may be said that fair competition is allowed for Muslims including engineers.

b. However, an engineer should avoid unfair competition with his colleagues and also with engineers from other companies. Likewise, he should not be envious towards his colleagues because of their better performance. Islam forbade 
Muslims including engineers to envy each other. The Prophet (pbuh) said: "You should not compete each other [unfairly] and should not envy each other."[34] Allah taught Muslims to seek refuge from the harm of an envious person with Him when he practices envy. He said: "Say: 'I seek refuge with the Lord of the Dawn from the mischief of created things... and from the mischief of the envious one when he practices envy."[35]

c. Out of envy or unfair competition, an engineer should not try to oust another engineer or colleague from his post or job.

d. However, he is supposed to develop his carrier within the guidelines of his own office or company, which fall under fair and lawful competition.

\subsection{Continuous Struggle towards Perfectness}

a. An engineer is supposed to do his work as perfect as possible. The Prophet (pbuh) said: "Surely Allah loves one from among you who, when he accomplishes any work, accomplishes it perfectly."[36] Since the word "any work" ('amal) in this hadith is a general expression, it includes both worship and other mundane deeds that a human being does in his daily life. Likewise, the phrase "one from you" is a general expression that includes all different types of doers and workers, one of whom is an engineer.

b. Perfectness of works of an engineer requires knowledge of these works. Therefore, he should try to have up-to-date knowledge of the development in his field of specialization. Allah said through the mouth of the Prophet Yusuf: "Appoint me the supervisor of treasuries of the earth, for I am a very knowledgeable guard/supervisor."[37] Since Yusuf had perfect knowledge of supervising the treasuries, he was appointed by Pharaoh to perform this duty. Accordingly, an engineer should have perfect up-to-date knowledge of his field; otherwise he will be not able to do his work perfectly. However, if any training is required to have up-to-date knowledge of his field, his employer should arrange training program for him.

c. Struggle for perfectness in his works should be a continuous effort for him as long as he is in his profession. Since an engineer, as a Muslim continuously tries to perfect his worship for Allah, he is also supposed to try continuously to perfect his worldly affairs including employment and other works for getting sustenance. Allah loves to see His servant tired because of struggling for sustenance. The Prophet said: "Surely Allah loves to see His servant tired because of seeking lawful sustenance."[38]

d. An engineer should not be a lazy person. Islam does not like laziness. The prophet taught all Muslims including an engineer to seek refuge with Allah from laziness by saying: "O Allah, surely I take refuge with you from anxiety, sorrow, inability and laziness..."[39]

e. An engineer should be ready to accept constructive criticism of his works by other colleagues because this is a way to improve and become free from mistakes.

f. An engineer who is in charge of a project should not delay to complete it without any valid reason because it would cause financial loss to the owner of the project and would damage the reputation of himself and his company. This goes against a hadith in which Muslims including an engineer are encouraged to struggle for perfection of their works. Delaying a project against this perfection.

\section{CODE OF ETHICS OF TWO ENGINEERING SOCIETIES}




\subsection{Code of Ethics of Institution of Engineering, Bangladesh (IEB)}

1. "I solemnly promise that as a member of The Institution of Engineers, Bangladesh I shall uphold and advance the integrity, honor and dignity of the engineering profession using my knowledge and skill and shall hold paramount the safety, health and welfare of the public and shall try to comply with the principles of sustainable development ${ }^{\mathrm{i}}$ in the performance of my professional duties.

2. I shall be honest and impartial and serve with complete fidelity the public, employer and clients. I shall not accept remuneration for services rendered other than that from my employer or with my employer's permission.

3. I shall perform services only in areas of my competence.

4. I shall build my professional reputation of the merit of my services and shall not compete unfairly with others.

5. I shall act in professional matters for my employer or client as faithful agent or trustee and shall avoid conflict of interest and avoid deceptive acts.

6. I shall issue public statements only in an objective and truthful manner, and shall not in a self-laudatory language or in any manner derogatory to the dignity or the profession, or professional bodies, neither advise or write articles for publication, nor shall authorize such advertisements to be written or published by any other person.

7. I, without disclosing the fact to my employer in writing shall not be director of or have a substantial financial interest in, nor be an agent for any company, firm or person carrying on any contracting, consulting or manufacturing business which is or may be involved in the work to which my employment relates, nor shall I receive directly or indirectly any royalty, gratuity or commission or any article or process used in or for the purpose of the work in respect of which I am employed unless or until such royalty, gratuity or commission has been authorized in writing by the employer.

8. I shall support the professional and technical societies of my discipline.

9. I, in connection with work in country other than my own shall order my conduct according to these rules, as far as they are applicable; but where the country has recognized standards of professional conduct, I shall adhere to them.

10. I shall not offer, guide, solicit or receive, either directly or indirectly any political contribution in an amount intended to influence the award of a contract by the public authority.

11. I solemnly promise I shall avoid bribery and extortion in any form. If I encounter such acts done by any member, I shall be ethically bound to report it to the Ethical Review Board (ERB) of IEB (ERB is to be formed).

12. I shall continue my professional development throughout my career, and shall provide opportunities and support for the professional development of the engineers under my supervision.

13. A member who shall be convicted by a competent tribunal of a criminal offence, which in the opinion of the disciplinary body renders him unfit to be a member, shall deemed to have been guilty of improper conduct.

Signature

Name

Membership no F/M/AM (to be filled up by office)"'[40]

\subsection{Boar of Engineers, Malaysia (BEM) Code of Professional Conduct}


A number of codes of ethics have been prescribed by BEM. This paper touches on only the code of ethics prescribed for the matured professional engineers of Malaysia. Following is the full text of this code:

\section{A. Definition of Employer}

1. Unless it is otherwise expressly provided, the expression 'employer' shall for the purposes of this part, include client.

\section{B. Conduct of Registered Engineer}

2. A Registered Engineer shall order his conduct so as to uphold the dignity, standing and reputation of the profession.

\section{Responsibility to Employer and Profession}

3. A Registered Engineer in his responsibility to his employer and the profession shall have full regard to the public interest.

\section{Discharge of Duties}

4. A Registered Engineer shall discharge his duties to his employer with complete fidelity. He shall not accept remuneration for services rendered other than from his employer or with his employer's permission.

\section{E. Reputation etc. of a Registered Engineer not to be Injured}

5. A Registered Engineer shall not maliciously injure or attempt to injure whether directly or indirectly, the professional reputation, prospects or business of another Registered Engineer.

\section{F. Canvassing and Advertising Prohibited}

6. A Registered Engineer shall not improperly canvass or solicit professional employment nor offer to make by commission or otherwise payment for the introduction of such employment. He shall not advertise except for the purpose of obtaining salaried appointment as permitted by the Board.

\section{G. A professional Engineer in private practice not to practice with any person whose registration has been cancelled}

7. A Professional Engineer in private practice shall not practise engineering with any person whose registration has been cancelled unless he has been reinstated under section 17(1) of the Act.

H. A salaried Registered Engineer not to compete with professional Engineers in private practice

8. A Registered Engineer shall not use the advantage of a salaried position to compete with professional Engineers in private practice.

\section{Restriction on submission of plans and drawings}

9. (1) No registered Engineer other than a professional Engineer in private practice may submit plans or drawings to any person or authority in the federation unless such plans or drawings are in connection with equipment, plant or specialized products manufactured or sold by his employer or firm, or in connection with his own or his employer's engineering works and buildings. (2) For the purpose of this rule, "employer" shall not include client. 
IIUM Engineering Journal, Vol. 12, No. 5, 2011: Special Issue on Science and Ethics in Engineering

Amanullah

\section{J. Restriction on making payments or placing contracts}

10. A Professional Engineer in private practice shall not be medium of payment made on his client's behalf unless he is so requested by his client nor shall he, in connection with work on which he is employed, place contracts or orders except with the authority of and on behalf of his client.

\section{K. Restriction on entering professional partnership}

11. A Professional Engineer in private practice shall not without the occurrence of the Board enter into professional partnership with any person other than a Professional Engineer in Private practice, a Registered Architect, a Registered Surveyor or a Licensed Land Surveyor.

\section{A Professional Engineer in private practice not to intervene or to take over the work of another}

12. A Professional Engineer in private Practice shall not, directly or indirectly attempt to supplant another Professional Engineer in private practice nor shall he intervene or attempt to intervene in or in connection with engineering work of any kind which to his knowledge has already been entrusted to another Professional Engineer in Private practice nor shall he review or take over the work of that other Engineer acting for the same employer, until he has either obtained the consent of that Engineer or has been formally notified by the employer that the engagement of that Engineer with work has been properly terminated.

\section{A Professional Engineer in Private Practice shall not be a contractor}

13. (1) A Professional Engineer in Private Practice shall not be a contractor at the same time.

(2) A Professional Engineer in Private Practice shall not act in a professional capacity for an employer and a contractor on the same project unless on the specific instructions of the employer."[41]

\section{EVALUATION, COMPARISON AND SUGGESTIONS}

\subsection{Evaluation}

The code of ethics of IEB is considered to be one of the best codes of ethics prescribed by many engineering associations all over the world. It is good that at the beginning of this code the phrase "solemnly promise" has been mentioned. This phrase makes this code binding for the members of IEB. All the ethics mentioned in this code are considered to be good and justified. But nowhere it mentions name of Allah, the Prophet (pbuh), Islam, Shari 'ah, the Qur'an, Sunnah or Muslims. By reading this code there is no way to figure it out that it has been prepared by Muslims. Same types of ethics have been prescribed by other engineering associations in America and Europe by non-Muslims. Since majority of the engineers of Bangladesh are Muslims, it should indicate that through this code they try to follow the rulings of the Shari ah prescribed by Allah. Although the ethics mentioned in this code Islamically supported, it is not appropriate to consider them as Islamic code of ethics because in order to make a code Islamic there should be an intention and declaration openly that this code will not violate the Shariah and if any contradiction occurs between these ethics and between what is prescribed by the Qur'an and Sunnah, the latter will dominate the former. In any case, the researcher does not consider this code as a comprehensive code of ethics for Muslim engineers. In order to 
improve this code and make it as a comprehensive code of ethics for Muslim engineers, the researcher will later provide some suggestions.

Likewise, the code of professional conduct of BEM is also considered good because all the ethics mentioned in this code are justified. There is no mention of promise to abide by these ethics. However the phrases like "shall order," "shall have," "shall not," etc. used in this code make it binding to the members of BEM but with lesser degree of obligation. It is understood that since there are many non-Muslim engineers in Malaysia, it is not appropriate to mention name of Allah, the Messenger, Shariah, Islam, the Qur'an, Sunnah, or Muslims in it. Although the ethics mentioned in this code are Islamically supported, the researcher does not consider it as a comprehensive code of ethics for Malaysian Muslim engineers. Likewise, the researcher finds that this code of ethics is less comprehensive than the code of ethics prescribed by BEM for its young engineers. In order to make it comprehensive code for Malaysian Muslim engineers, the researcher will later provide some suggestions.

\subsection{Comparison}

In this sub-section the researcher strives to make comparison between the code of IEB and the code of BEM by discussing their similarities and differences as follows:

\section{A. Similarities}

1. Both of them are good because ethics mentioned in them are Islamically justified.

2. Both of them do not say clearly that it is an Islamic code of ethics for engineers.

3. Both of them avoid making an oath in the name of Allah or God at the beginning.

4. It is a coincidence that both of them have the similar numbers of ethics, i.e., 13.

5. Both of them do not quote any source for the code.

6. Both of them have varying degree of obligatory or binding nature.

7. Both of them are not binding for engineers who are not members of them.

8. Both of them have some similar ethics.

\section{B. Differences}

1. The code of IEB is considered to be more binding for its members than the code of BEM. This is because IEB uses the phrase "solemnly promise," whereas BEM uses phrase like "shall order," "shall have," "shall not," etc. Additionally, IEB uses first person like "I,", "my", etc. which carry more seriousness and strength than the third person like "He," "Professional Engineer," "Registered Engineer," etc. used by the code of BEM. Moreover, at the end of the code of IEB there is a place for signature of the member who should sign his name on this code; while the code of BEM does not have a place for signing it by its member.

2. All 13 points mentioned in the code of IEB are considered ethics, while the point number one of the code of BEM is not considered to be an ethic because it provides the definition of employer.

3. Some points mentioned by the code of IEB, such as to comply with the principles of sustainable development, and to adhere to the standards of professional conduct of another country in the case of presence of its member in that country, etc., are not mentioned by the code of BEM.

4. Some points mentioned by BEM, such as to be ready to accept peer review, to be transparent, not to try to oust other engineers from their post or job, to be meticulous in certification of a work, etc. are not mentioned by IEB.

5. BEM provides a sub-title for each of its ethics, while IEB does not follow this method. Rather, depends on the numbers only. 


\subsection{Suggestions}

1. Both Bangladesh and Malaysia have engineers from different religious groups. Therefore, the researcher suggests that each country should consider its present code of ethics for non-Muslims. Both countries should prepare a separate code of ethics for Muslim engineers by keeping all present points of ethics and adding several new points to them to make it as a comprehensive Islamic code of ethics for Muslim engineers.

2. At the beginning of the code, taking oath in the name of Allah should be mentioned by both codes.

3. The code of BEM should use the phrase "solemnly promise" to make it more serious.

4. Both codes should clearly mention that they will follow the rulings of Shariah prescribed by Allah.

5. Both should strongly state that their members will not involve themselves with any forbidden project. Rather, they will strive continuously to earn, invest and work in lawful projects.

6. Both should have a plan to help needy and poor people of the society.

7. Both should declare not to do any project that goes against the environment.

8. BEM should focus on sustainable development.

9. Both should clearly say that they will not develop any project or business complex that is known to be used for obscene deeds.

10. Both should state that if any contradiction happens between the rulings of Shari ah and between these ethics the former will be prevalent.

11. Both should have policy that if any contradiction occurs between personal interest and public interest the latter should be prevalent.

12. Both should have policy for their members to increase their knowledge and to have up-to-date information in their specializations.

13. Both should declare to follow the rules of supervision, checking and report writing.

14. Both should declare that all member engineers should obey their superiors and employers.

15. Both should promise not to develop any computer program or soft wires that are harmful in terms of losing the character and also in terms of monitory loss, such as damage of the computer itself by making viruses.

16. Engineering ethics should be imposed by the government on all engineers whether they are members of any society or not.

\section{CONCLUSION}

The most important findings of this research are as follows:

1. An engineer should give utmost importance and priority to the public health and safety.

2. An engineer should be trustworthy and responsible.

3. An engineer should not offer or receive bribe.

4. An engineer should be truthful and sincere in all of his activities related to his professional life.

5. An engineer should try to help poor people who need their expertise but cannot afford the cost. 
6. An engineer should work for lawful and beneficial projects. He should avoid building projects or soft wires that are Islamically illegal and harmful for the public.

7. An engineer should struggle for sustainable development.

8. An engineer should avoid unfair competition with other engineers and employees.

9. An engineer should continuously try for perfectness and excellence in his profession.

10. Although ethics mentioned in the codes of both IEB and BEM are good and justified, they are not considered Islamic ethics of engineering because no where they declare that they follow these ethics for the sake of abiding them by the rulings of the Shariah.

11. There are a number of similarities as well as differences between the code of ethics of IEB and BEM. However, the code of IEB seems to have more binding and obligatory nature than the code of BEM.

12. None of the codes of ethics of IEB and BEM are considered to be Islamically comprehensive. In order to make them Islamically comprehensive, a number of ethical points must be added to them. The most important of these added ethics is that they should declare in their codes that they will follow the rulings and guidelines of the Shari ah and whenever there will be any contradiction between their codes and between the rulings of the Shari ah the latter will be prevalent.

13. The researcher proposes that the present codes of IEB and BEM more or less suitable for non-Muslims. They are not completely suitable for Muslim engineers. Therefore, a separate code for Muslim engineers should be developed by incorporating suggestions provided by the researcher in this research paper.

\section{REFERENCES}

[1] Abdi Omar Shuriye and Ahmad Faris Ismail, Qur'anic Values and Engineering Studies (Petaling Jaya: Pearson Malaysia Sdn. Bhd., 2011), pp. 1-5.

[2] The researcher has arrived to this definition according to his understanding of the texts of the Qur' an and ahadith of the Prophet (pbuh) related to the profession of engineering.

[3] Shuriye, et al., Qur'anic Values and Engineering Studies (Petaling Jaya: Pearson Malaysia Sdn. Bhd., 2011).

[4] Qur'an surah Al-Nisa', 4: 59

[5] Qur' an surah Al-Ma'idah, 5: 32

[6] Muhammad bin Yazid Abu `Abd Allah bin Majah, Sunan ibn Majah, ed. Muhammad Fu'ad 'Abd al-Baqi (Beirut: Dar al-Fikr, n. d.), vol. 2, p. 784.

[7] Qur'an surah Al-Nisa', 4:58.

[8] Musnad al-Imam Ahmad. See Qutub Mustafa Sano, Al-Istithmar Ahkamuhu wa Dawabituhu fi al-Fiqh al-Islami (Jordan: Dar al-Nafa'is, 2000), p. 155.

[9] Qur'an surah Hud, 11: 85.

[10] Muslim. See Abu Zakariyya Yahya bin Sharaf al-Nawawi al-Dimashqi, Riyad al-Salihin, ed. Shu ayb al-Arnabut (Beirut: Ma'assasat al-Risalah, 1991), p. 599.

[11] Sunan ibn Majah. See Muhammad Sabri Harun, Ahkam al-Aswaq al-Maliyyah (Jordon: Dar al-Nafa'is, 1999), p. 162.

[13] Ahmad bin `Ali bin Hajar al-`Asqalani, Fath al-Bari Sharh Sahih al-Bukhari, $4^{\text {th }}$ ed. (Beirut: Dar al-Kutub lil-Tiba ah wa al-Nashr, 1984), vol. 5, p. 474.

[14] Qur'an surah Al-Hujurat, 49: 12.

[15] Qur'an surah Al-Hujurat, 49: 6. 
IIUM Engineering Journal, Vol. 12, No. 5, 2011: Special Issue on Science and Ethics in Engineering Amanullah

[16] Qur'an surah Al-A'raf, 7: 199.

[17] Qur'an surah Al-Nahl, 16: 90.

[18] Qur'an surah Al-Tawbah, 9: 119.

[19] Qur'an surah Al-Isra', 17: 36.

[20] Tabrani. See Ibrahim Isma`il, Al-I lam al-Islami wa Wasa'il al-Ittisal al-Hadithah (Makkah al-Mukarramah: Rabitat al-`Alam al-Islami, 1994), p. 32; Muslim. See al-Dimashqi, Riyad al-salihin, p. 599.

[21] Bukhari and Muslim. See al-Dimashqi, Riyad al-Salihin, p. 321.

[22] Al-Tirmidhi, Al-Darami, al-Darqutni. See Al-Shaykh Wali al-Din Muhammad bin `Abd Allah al-Khatib al-Tabrizi, Mishkat al-Masbih (Lahore: Maktaba'i Mustafa'i, n. d.), p. 243.

[23] Bukhari and Muslim. See al-Dimashqi, Riyad al-salihin, p. 148.

[24] Muslim. See al-Dimashqi, Riyad al-salihin, p. 149.

[25] Qur'an surah Al-Nahl, 16: 90.

[26] Qur'an surah Al-Nur, 24: 19.

[27] Qur'an surah Al-An`am, 6: 151.

[28] Qur'an surah Al-Baqarah, 2: 172.

[29] Al-Imam al-Mundhiri. See Amirah `Abd al-Latif Mashhur, Al-Istithmar fi al-Iqtisad alIslami (Cairo: Maktabat Madbuli, 1991), p. 255.

[30] Al-`Asqalani, Fath al-Bari Sharh Sahih al-Bukhari, vol. 5, p. 22.

[31] 'Izz al-Din al-Khatib al-Tamimi, Al Amal fi al-Islam: Akhlaquh, Mafahimuh, Qiyamuh, Ahkamuh (Amman: dar `Ammar, n.d.), p. 40.

[32] Qur'an surah Al-Baqarah, 2: 148.

[33] Qur'an surah Al-Ma'idah, 5: 2.

[34] Muslim. See al-Dimashqi, Riyad al-salihin, p. 595.

[35] Qur'an surah Al-Falaq, 113: 1-5.

[36] 'Izz al-Din Baliq, Minhaj al-Salihin min Ahadith wa Sunnat Khatim al-Anbiya ' wa alMursalin, $3^{\text {rd }}$ ed. (Beirut: Dar al-Fath lil-Tiba' ah wa al-Nashr, 1984), p. 384.

[37] Qur'an surah Yusuf, 12: 55.

[38] Qur'an surah Yusuf, 12: 210.

[39] Al-'Asqalani, Fath al-Bari Sharh Sahih al-Bukhari, vol. 11, p. 207.

[40] The Institution of Engineers, Bangladesh, Constitution of the Institution of Engineers, Bangladesh (Dhaka: The Institution of Engineers, Bangladesh, 2005), Appendix-A.

[41] Board of Engineers Malaysia (BEM), (Melaka: Faculty of Engineering and Technology, Multimedia University, 2010). http://fet.mmu.edu.my/v4/career/bem.html 